\title{
Estimation of HCV viral load and liver enzymes among different patients groups of District Gujrat, Pakistan
}

\author{
Asim Mushtaq ${ }^{1}$, Mujahid Azeem Tariq ${ }^{2}$, Umer Rashid $^{1}$, Amber Afroz ${ }^{1}$, Nadia Zeeshan ${ }^{1}$, \\ Abdul R. Asif ${ }^{3}$, Muzna Zahur ${ }^{1,4^{*}}$ \\ ${ }^{1}$ Department of Biochemistry and Molecular Biology, University of Gujrat, Gujrat, Pakistan \\ ${ }^{2}$ Department of Pathology, Hashmat Medical College, Gujrat, Pakistan \\ ${ }^{3}$ Department of Clinical Chemistry, University Medical Centre, Goettingen, Germany \\ ${ }^{4}$ Department of Neurology, University Medical Centre, Goettingen, Germany \\ Email: ${ }^{*}$ mzahur@yahoo.com
}

Received 9 July 2013; revised 9 August 2013; accepted 25 August 2013

Copyright (C) 2013 Asim Mushtaq et al. This is an open access article distributed under the Creative Commons Attribution License, which permits unrestricted use, distribution, and reproduction in any medium, provided the original work is properly cited.

\begin{abstract}
Hepatitis C has a $3 \%$ of the global disease burden that remains endemic in many regions of the world. According to a general statistical survey it has approximately $5.3 \%$ seroprevalence in Pakistan. HCV is a persistent and silent disease thus making the primary diagnosis complicated. Occasionally HCV positive population could not be diagnosed by routine HCV antibody testing therefore requires molecular diagnosis. This study is aimed to determine the prevalence of HCV and to estimate the HCV viral load by quantitative analysis among different patient groups of District Gujrat, Pakistan. A total of 597 samples were collected from clinically diagnosed liver patients that were categorized into three age groups: 1) up to 25 years; 2) 26 - 50 years 3 ) above 50 years. All samples were subjected to real time PCR for determination and quantification of HCV RNA. Activity of liver aminotransferases was measured. The overall prevalence of HCV-RNA was $73.87 \%$. Females had slightly higher HCV prevalence which is $74.06 \%$ while $73.45 \%$ in males. Highest prevalence of active HCV infection was found in age group 26 - 50. In addition, liver function tests showed that $28.12 \% \mathrm{HCV}$-positive patients do not have elevated ALT level whereas $32.65 \%$ did not show elevated AST levels. It may be assumed that there is not a significant relationship between increased viral load and liver amino transferases. The study concluded a significantly higher rate of $\mathrm{HCV}$ infection in young population. Moreover screening with antibody and liver function tests alone does not exclude the possibility of HCV infection.
\end{abstract}

\footnotetext{
"Corresponding author.
}

Keywords: Hepatitis C; Viral Load; Alanine Aminotransferase; Aspartate Aminotransferase; HCV RNA; Gujrat

\section{INTRODUCTION}

Hepatitis $\mathrm{C}$ virus (HCV) is a widespread infection that causes significant morbidity and mortality all over the world [1]. HCV infection is often asymptomatic and almost in $70 \%$ cases leads to chronic hepatitis. This may results in cirrhosis, liver failure, hepatocellular carcinoma or progressive liver disease within 20 to 30 years. Viral load is one of the factors associated with progression of disease in $\mathrm{HCV}$ infection [2]. Hepatitis $\mathrm{C}$ was first discovered in 1989, at that time it was thought of minor importance because of its difference from both hepatitis A and B. At present it has become one of the major global health issue that needs to be actively controlled and prevented [3].

Around the globe, approximately $130-170$ million persons are living with chronic hepatitis $\mathrm{C}$ virus infection [4]. Egypt has the largest burden of HCV in the world, with $10 \%$ prevalence of chronic HCV infection among the persons aged $15-59$ years [5]. It is also a common chronic blood-borne infection in USA, causing an estimated $8000-10,000$ death annually which will be increased substantially in the next 20 years [6]. There are almost 10 million people with HCV infection in Pakistan [7].

Chronic HCV is usually treated with interferon (IFN) alpha (a glycoprotein) that is considered as a backbone of $\mathrm{HCV}$ treatment because of its efficient role to enhance the immune response against virus [8]. At present, pegelated interferon (PEG-IFN) in combination with ribavirin is regularly used for HCV treatment. This therapy achieves 
about $80 \%$ SVR for genotype $2 \& 3$ and $50 \%$ for genotype 1 [9]. Pegelated interferons are of two types, PEGIFN-alpha-2a and PEG-IFN-alpha-2b. They are different in their size and configuration of the polyethylene glycol that contains binding sites for interferon. The two formulated interferons are equally good for HCV treatment but their functioning is not compared [10]. Pre viral loads are useful determinants of response to antiviral therapy [11], hence initial viral load and decrease of viral load at initial stage of antiviral therapy are useful parameters to check efficacy and to optimize antiviral therapy [12].

There are different parameters for HCV diagnosis. In most of the cases HCV prognosis is based on liver function tests. Abnormal level of serum amino transaminases may lead to the prognosis of $\mathrm{HCV}$ infection. ALT is most intense in liver and released into the bloodstream as the result of liver damage that fairly indicates liver status [13]. In fact, before the detection of HCV and the exploitation of molecular based essays for HCV RNA, the non-A, non-B hepatitis was based on records of steadily abnormal ALT levels [14]. On the other hand, almost $25 \%$ of patients with active HCV infection have persistently normal ALT values [15]. It is considered that occult-HCV (characterized by presence of liver disease and absence or very low levels of detectable HCV-RNA in serum) can be indicated by abnormal liver function tests although virus may persist for years after spontaneous recovery or after sustained viral response [16]. In this scenario, Viral Load is a good parameter for the presence of hepatitis $\mathrm{C}$ virus and it also measures the amount of $\mathrm{HCV}$ in the blood. If viral load (RNA) is found significantly in an individual's blood, it confirms active infection [17]. If viral load is less than $800,000 \mathrm{IU} / \mathrm{mL}$, it is considered as low viral load while more than 800,000 $\mathrm{IU} / \mathrm{mL}$, is called high viral load [18]. In the present study patient data were collected from densely populated District Gujrat of Pakistan and tested for the presence of $\mathrm{HCV}$ infection with molecular analysis. Quantification of viral load was done to estimate the disease progression and compared with liver enzymes activity. The data showed high HCV prevalence in young population particularly in females. Also a discrepancy was found between viral load and liver function tests.

\section{MATERIAL AND METHODS}

\subsection{Sample Collection}

A total of 597 blood samples were collected in a well known diagnostic lab and its collection centres located in different remote areas of Gujrat (a district of province Punjab, Pakistan). Informed consent was added in laboratory software from each patient including name, sex, age, address and contact number. Blood samples were collected in $5 \mathrm{~mL}$ chilled, sterilized disposable syringes.
Serum separation was done in $1.5 \mathrm{~mL}$ eppendorf tubes at $13,000 \mathrm{rpm}$ for $2 \mathrm{~min}$ and used fresh or stored at $-20^{\circ} \mathrm{C}$. All analysis was done in accordance with the ethical standards mentioned in the declaration of Helsinki.

\subsection{RNA Extraction and Quantification}

Total viral RNA was extracted from $150 \mu \mathrm{L}$ serum samples by using Nucleospin RNA virus extraction kitaccording to the manufacturer's instructions. Finally each RNA sample was dissolved in $50 \mu \mathrm{L}$ TE buffer.

HCV RNA was amplified by using real time amplification and detection kit HCV Real-TM Quant (Sacace Biotechnologies, Italy). Fluorescently labelled HCV specificprobes were used (reporter dye: cy3). FAM dye was used to amplify HCV internal control (IC). Internal control was provided as an amplification control for each sample being processed to detect the possible contamination risks. Two positive controls for different quantities (quantities of standard $125 \mathrm{IU} / \mathrm{mL}$ and 12,500,000 IU/mL) and two negative controls were carried out using cDNA as substrate and spiked with mimic target in each run. From the total RNA extracted, $12.5 \mu \mathrm{L}$ was used as template and mixed with equal volume of super mix containing $300 \mu \mathrm{L}$ of RT-PCR-mix-1, $200 \mu \mathrm{L}$ of RT-PCRmix-2, $20 \mu \mathrm{L}$ of Hot Start Taq Polymerase and $10 \mu \mathrm{L}$ of M-MLV Revertase. Amplification was carried out by standard method (Stage 1: $50^{\circ} \mathrm{C}$ for $1800 \mathrm{sec}$, stage 2: $95^{\circ} \mathrm{C}$ for $900 \mathrm{sec}$ and stage $3: 95^{\circ} \mathrm{C}$ for $20 \mathrm{sec}$ and $60^{\circ} \mathrm{C}$ for $40 \mathrm{sec}$ for 42 repeats. PCR reaction was performed in Smart cycler 11 (Cepheid, Germany). Results were analyzed by using smart cycler software v2.0d. Viral load was calculated with the help of $\mathrm{Cy} 3$ and FamCt value $($ Cy3 STD/Fam STD $\times 510,000=$ No. of HCV IU $/ \mathrm{mL})$.

\subsection{Assessment of ALT and AST}

ALT and AST levels were measured using Ecoline reagents according to manufacturer's instructions. The threshold of $42 \mathrm{IU} / \mathrm{L}$ was used as upper normal range for ALT and $40 \mathrm{IU} / \mathrm{L}$ for AST. Both enzyme activities were measured at the same time when PCR for HCV quantification was run.

\subsection{Statistical Analysis}

Relationship of viral load with ALT and AST in both males and females was analysed by determining Correlation Coefficient. Correlation was significant at 0.01 level (2-tailed). Correlation coefficient was performed by using commercially available computer program SPSS (SPSS16.0).

\section{RESULTS}

A total of 597 proposed anti HCV samples (171 detected 
by ELISA and 426 by ICT) were collected in Dr. Mujahid's lab and FNA clinic district Gujrat and from its different collection centres. Out of 597 individuals 374 were females and 223 were males. All the individuals were categorized in three age groups (1st group: up to 25 years, 2nd group: 26 - 50 years, 3rd group: Above 50 years).

Sinceanti HCV antibodies are unable to show active $\mathrm{HCV}$ infection in some cases therefore, all the samples were subjected to RNA extraction and RT PCR to check active infection. The PCR results detected HCV RNA in the serum of $441(73.87 \%)$ individuals. In males, 164 (73.45\%) of 221 showed active HCV infection due to presence of HCV RNA in their serum while in females $277(74.06 \%)$ of 374 had active infection. Quantification analysis further demonstrated that that population in $3 \mathrm{rd}$ age group is at higher risk then the other two groups where more than $70 \%$ of people have viral titre higher than $800,000 \mathrm{IU} / \mathrm{mL}$ (Table 1). Distribution of active $\mathrm{HCV}$ infection according to the sex and age is given in Figures 1(a) and (b).

Liver function tests (ALT and AST) were performed for the individuals with active infection. Among 441 confirmed patients of active HCV, 317 (71.88\%) had elevated ALT level and 297 (67.35\%) had elevated AST level (Table 2).

The correlation between viral load and ALT is more significant than the correlation between viral load and AST in females. Similarly, in case of males viral load and ALT had more significant relation than viral load and AST. Generally, males have strong relationship of ALT and AST with viral load than females (Figures 2(a) and (b)).

Table 1. HCV RNA viral load distribution in males and females.

\begin{tabular}{cccc}
\hline & Age & $<\mathbf{8 0 0 , 0 0 0 ~ I U / m L}$ & $>\mathbf{8 0 0 , 0 0 0 ~ I U / m L ~}$ \\
\hline \multirow{3}{*}{ Females } & $\leq 25$ & $34.78 \%(8 / 23)$ & $65.21 \%(15 / 23)$ \\
& $26-50$ & $41.63 \%(92 / 221)$ & $58.37 \%(129 / 221)$ \\
& $>50$ & $27.27 \%(9 / 33)$ & $72.73 \%(24 / 33)$ \\
\multirow{2}{*}{ Males } & $\leq 25$ & $36.36 \%(8 / 22)$ & $63.64 \%(14 / 22)$ \\
& $26-50$ & $31.58 \%(36 / 114)$ & $68.42 \%(78 / 114)$ \\
& $>50$ & $28.57 \%(8 / 28)$ & $71.43 \%(20 / 28)$ \\
\hline
\end{tabular}

Table 2. Comparison of liver function tests with HCV viral load.

\begin{tabular}{|c|c|c|c|c|c|}
\hline HCV RNA titer (IU/mL) & No. of patients & $\begin{array}{c}\text { Serum ALT level } \\
(\text { mean } \pm \text { SD) }\end{array}$ & $\begin{array}{c}\text { Serum AST level } \\
(\text { mean } \pm \text { SD) }\end{array}$ & $\begin{array}{c}\text { Serum abnormal ALT } \\
\text { (\%age) }\end{array}$ & $\begin{array}{c}\text { Serum abnormal ALT } \\
\text { (\%age) }\end{array}$ \\
\hline$\leq 10^{4}$ & 89 & $47.30 \pm 27.69$ & $44.02 \pm 23.44$ & $37.08(33 / 89)$ & $35.95(32 / 89)$ \\
\hline $10^{5}$ & 96 & $74.22 \pm 53.57$ & $59.52 \pm 36.41$ & $76.04(73 / 96)$ & $65.62(65.62)$ \\
\hline $10^{6}$ & 161 & $87.34 \pm 73.35$ & $70.21 \pm 47.91$ & $74.53(120 / 161)$ & 68.32 \\
\hline $10^{7}$ & 79 & $113.40 \pm 81.43$ & $87.49 \pm 47.57$ & $88.61(67 / 79)$ & $75.95(60 / 79)$ \\
\hline $10^{8}$ & 15 & $144.80 \pm 101.21$ & $120.13 \pm 67.01$ & $93.33(14 / 15)$ & $86.66(13 / 15)$ \\
\hline $10^{9}$ & 1 & 128 & $128 \pm 0$ & $100(1 / 1)$ & $100(1 / 1)$ \\
\hline
\end{tabular}

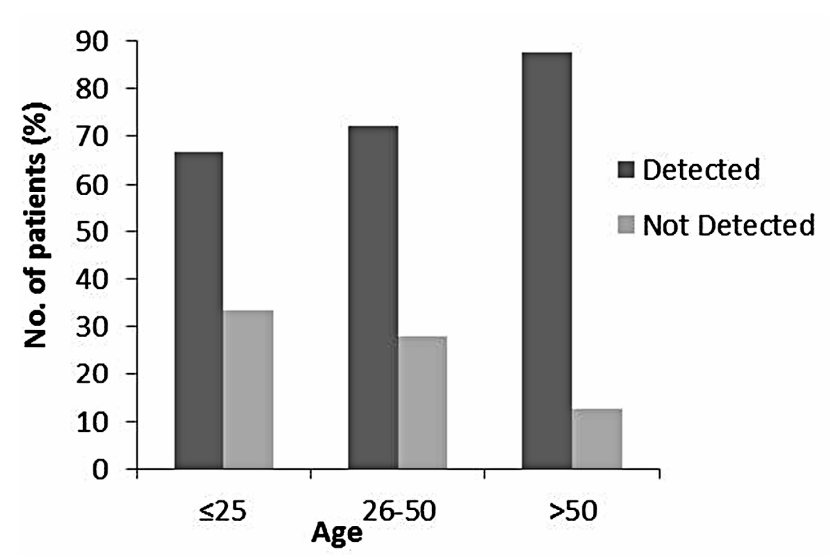

(a)

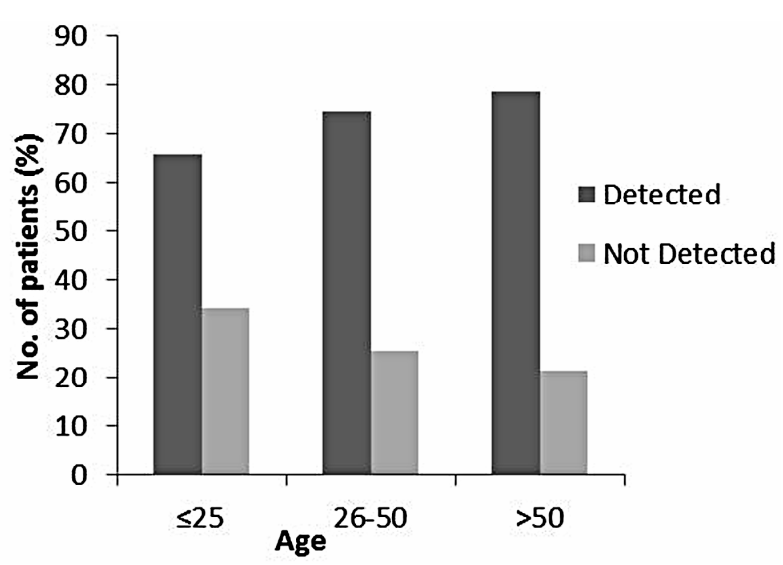

(b)

Figure 1. Distribution of active HCV Infection in (a) Males; (b) Females. 


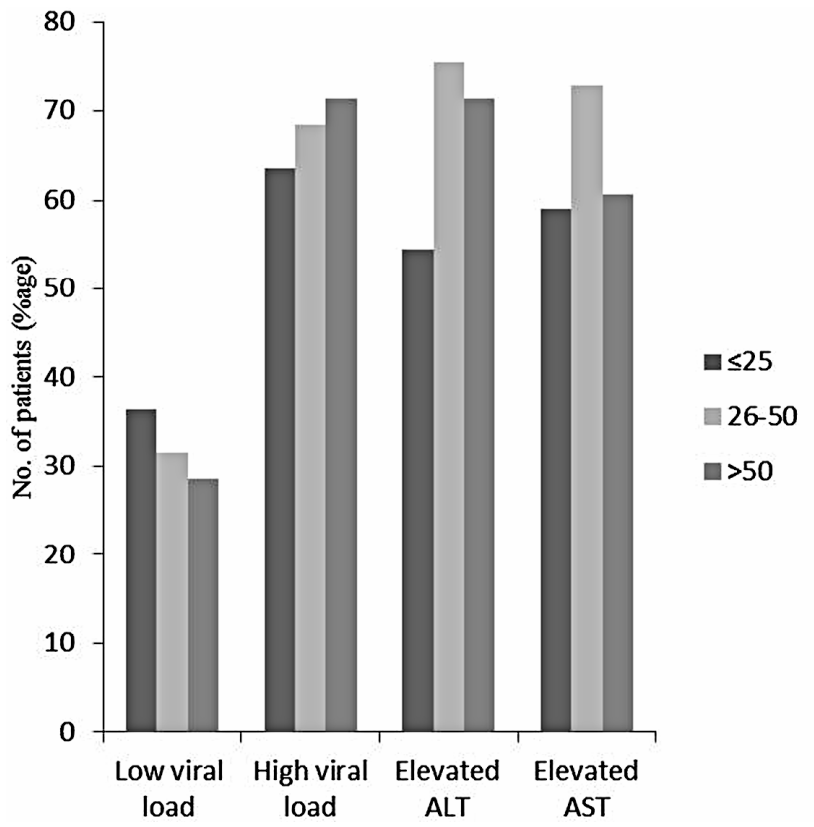

(a)

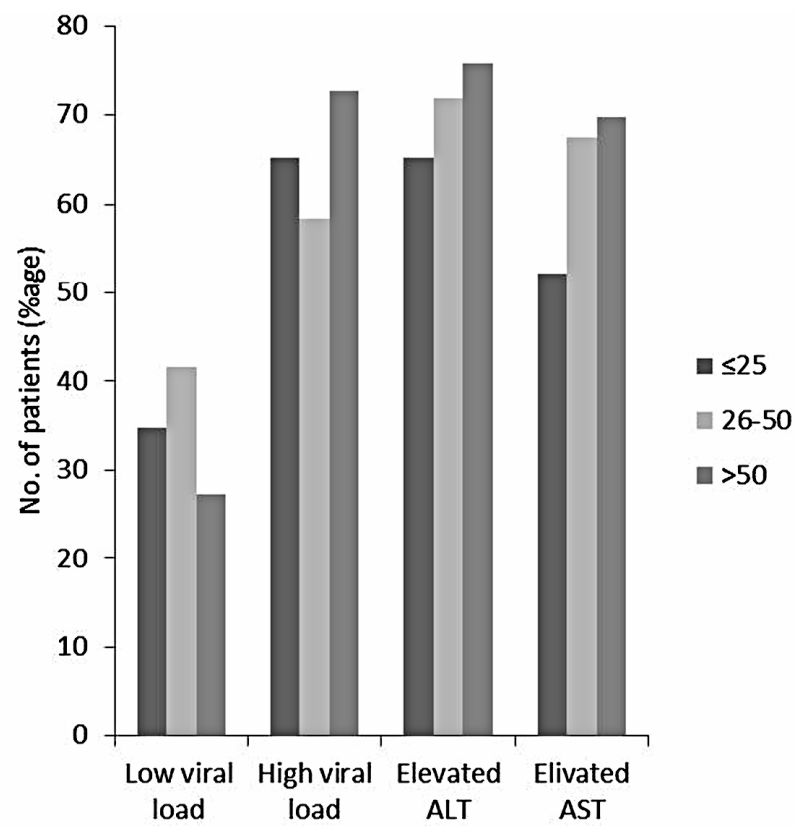

(b)

Figure 2. Relationship of viral load with ALT and AST (a) Males; (b) Females.

\section{DISCUSSION}

According to world health organization, there is about $3 \%$ world's population infected with hepatitis $\mathrm{C}$ in the world. Pakistan is one of the many developing countries where Hepatitis $\mathrm{C}$ is budding as a major health issue [19, 20]. Among the major causes of this dilemma are the absence of good preventive measures e.g. extensive reuse of non-sterilized syringes and razors, fragile health structure, unscreened blood transfusion, general poverty and poor education and high burden of immigrants have all affected epidemiology of HCV in Pakistan. Punjab is second largest province of Pakistan and has largest population. Gujrat is a densely populated district of Punjab located between two well-known rivers, the Jhelum and the Chenab. It is encircled on the northwest by the Jhelum River, on the northeast by Jammu and Kashmir and southeast by Chenab River and on the west by district Mandi Bahauddin [21].

Although Pakistan is at a high risk by HCV infection, However, national level estimates of the prevalence of and risk factors for hepatitis $\mathrm{C}$ are currently not available. Many scientists tried to explore the rate of HCV infection and found that it varies among different population groups and sexes like it is moderate in the general population but very high in injecting drug users and multitransfused populations [22]. Similarly Ali et al. [23] studied moderate to high prevalence and risk factors of hepatitis $\mathrm{C}$ in different areas of Pakistan. A weighted average of hepatitis C antibody was $3.0 \%$ (range $0.3 \%-31.9 \%$ ) that is even higher in the high-risk subgroups. Same is concluded by Umer et al. [24] who reviewed that the fre- quency of hepatitis $\mathrm{C}$ infection in Pakistan is high (4.7\%), varying from $0.4 \%-33.7 \%$, indicating pockets of infections. In present study we found the viral loads in relation with liver aminotransferases in active HCV infected individuals of both sexes constituting different age groups. All the patients were anti $\mathrm{HCV}$ positive. The results clearly indicated that all the anti $\mathrm{HCV}$ individuals had not active $\mathrm{HCV}$ infection. Our results indicated that there is a relation between liver aminotransferases and viral load. One case study conducted in district Mansehra Pakistan revealed there was $7 \%$ population having $\mathrm{HCV}$ antibodies while only $3.5 \%$ population had active $\mathrm{HCV}$ infection [25].

We studied a total 597 anti HCV patients of which 441 $(73.87 \%)$ had active infection. The purpose of our study was to check active HCV infection from anti HCV individuals by quantifying their viral load and to also verify the relationship of elevated liver aminotransferases with active $\mathrm{HCV}$ infection. We found that 150 of 171 anti $\mathrm{HCV}$ individuals detected by ELISA had active infection while 291 of 426 patients detected by ICT had active infection. This clearly illustrated that ELISA is better method for antibody detection than ICT because it gives less false positive results. In case of males, we found that $112(68.29)$ had high viral load and $52(31.70 \%)$ had low viral load in their serum, in females $168(60.64 \%)$ had high viral load and $109(39.35 \%)$. As if viral load is less than $800,000 \mathrm{IU} / \mathrm{mL}$, it is considered as low viral load while more than $800,000 \mathrm{IU} / \mathrm{mL}$, is called high viral load [15].

Abnormal level of serum transaminases may lead to 
the prognosis of HCV infection. One study showed that serum ALT levels, especially the AST levels were coupled with liver damage [26]. Usually it is considered that patients with chronic HCV having high HCV RNA titers and abnormal ALT levels show active HCV reproduction in liver and have higher risk of liver injury. Moreover, ALT level is used for indication of histological liver damage and a factor for starting therapy or to check antiviral therapy response in chronic hepatitis $\mathrm{C}$ [27]. We found that $71.88 \%$ patients with active $\mathrm{HCV}$ infection had elevated ALT level in their sera. As there are almost $25 \%$ of patients with active HCV infection having persistently normal ALT values [18]. We found $67.35 \%$ individuals with active $\mathrm{HCV}$ infection having elevated AST levels.

Patients with low viral load have 2.7 times more incidence of SVR than individuals with high viral load [28]. It is also prominent that individuals with high viral load show decreased response to antiviral therapy than individuals with low viral load and early prognosis reveals low HCV RNA viral load. Patients with high viral load should be treated for 24 weeks and those with low viral load might be treated for 16 weeks if there HCV RNA PCR is undetectable at 4 th week of treatment $[29,30]$. Our results indicate that $36.5 \%$ (161/441) have low viral load while $63.49 \%$ (280/441) have high viral load.

\section{CONCLUSION}

The prevalence of active $\mathrm{HCV}$ infection in anti $\mathrm{HCV}$ individuals increases with the increase in age. Individuals up to 25 years had less number of anti HCV antibodies and HCV RNA in their blood while with the increase in age the chances of active HCV infection increase and viral load also increases. Individuals with age $>50$ years have highest percentage of HCV RNA titer in anti HCV individuals. The viral load has a strong relationship with liver enzymes (ALT and AST). With the increase in viral load, the ALT and AST levels also increase in most cases but in some cases of active HCV infection ALT and AST levels remain normal.

\section{ACKNOWLEDGEMENTS}

We acknowledge support by the German Research Foundation and the Open Access Publication Funds of the Göttingen University.

\section{REFERENCES}

[1] Alter, H.J. and Seeff, L.B. (2000) Recovery, persistence. and sequelae in hepatitis $C$ virus infection: A perspective on long-term outcome. Seminars in Liver Disease, 20, 1735. doi:10.1055/s-2000-9505

[2] Freeman, A.J., Dore, G.J., Law, M.G., Thorpe, M., Von Overbeck, J., Lloyd, A.R., Marinos, G. and Kaldor, J.M. (2001) Estimating progression to cirrhosisin chronic he- patitis C virus infection. Hepatology, 34, 809-816. doi:10.1053/jhep.2001.27831

[3] Smith, D.B., Mellor, J., Jarvis, L.M., et al. (1995) Variation of the hepatitis $\mathrm{C}$ virus 5' non-coding region: Implications for secondary structure, virus detection and typing: The International HCV Collaborative Study Group. Journal of General Virology, 76, 1749-1761. doi:10.1099/0022-1317-76-7-1749

[4] Global Burden of Disease (GBD) for Hepatitis (2004) The Global Burden of Hepatitis C Working Group. Pharmacology, 44, 20-29.

[5] El-Zanaty, F. and Way, A. (2009) Egypt demographic and health survey 2008. Ministry of Health, El-Zanaty and Associates, and Macro International, Cairo.

[6] Williams, I. (1999) Epidemiology of hepatitis C in the United States. American Journal of Medicine, 107, 2S-9S. doi:10.1016/S0002-9343(99)00373-3

[7] Waheed, Y., Shafi, T., Safi, S.Z. and Qadri, I. (2009) Hepatitis $\mathrm{C}$ virus in Pakistan: A systematic review of prevalence, genotypes and risk factors. World Journal of Gastroenterology, 15, 5647-5653. doi:10.3748/wjg. 15.5647

[8] Caritter, R.L. and Emerson, S.S. (1997) Therapy of hepatitis-Meta analysis of interferon alpha $2 \mathrm{~b}$ trials. Hepatology, 26, 835-885.

[9] Fox, R.K. and Wright, T.L. (2003) Viral hepatitis: Current diagnosis and treatment. Gastroenterology, 2, 446562.

[10] Sherman, M., Shafran, S., Burak, K., Doucette, K., Wong, W., Girgrah, N., Yoshida, E., Renner, E., Wong, P. and Deschênes, M. (2007) Management of chronicnhepatitis C: Consensus guidelines. Canadian Journal of Gastroenterology, 21, 25C-34C.

[11] Yoshioka, K., Kakumu, S. and Wakita, T. (1992) Detection of hepatitis $\mathrm{C}$ virus bypolymerase chain reaction and response to interferon-a therapy: Relationship to genotypes of hepatitis C virus. Hepatology, 16, 293-299. doi:10.1002/hep.1840160203

[12] Ahmad, W., Ijaz, B., Javed, T.F., Jahan, S., Shahid, I., Khan, F.M. and Hassan, S. (2010) HCV genotype distribution and possible transmission risks in Lahore, Pakistan. World Journal of Gastroenterology, 16, 4321-4328. doi:10.3748/wjg.v16.i34.4321

[13] Lee, Y.S., Yoon, S.K., Chung, E.S., Bae, S.H., Choi, J.Y., Han, J.Y., Chung, K.W., Sun, H.S., Kim, B.S. and Kim, B.K. (2001) The relationship of histologic activity to serum ALT, HCV genotype and HCV RNA titers in chronic hepatitis C. Journal of Korean Medical Science, 16, 585-591.

[14] Dienstag, J.L. and Alter, H.J. (1986) Non-A, non-B hepatitis: Evolving epidemiologic and clinical perspective. Seminars in Liver Disease, 6, 67-81. doi:10.1055/s-2008-1040795

[15] Tassopoulos, N.C. (1999) Treatment of patients with chronic hepatitis C and normal ALT levels. Journal of Hepatology, 31, 193-196. doi:10.1016/S0168-8278(99)80400-0

[16] Carreno, V. (2006)Occult hepatitis C virus infection: A 
new form of hepatitis C. World Journal of Gastroenterology, 12, 6922-6925.

[17] Franciscus, A. (2012) Hepatitis C basics. Hepatitis C Support Project Vesion.

[18] Franciscus, A. and Highleyman, L. (2012) HCSP fact sheet: HCV diagnostic tools (Version 4).

[19] Raza, S.A., Clifford, G.M. and Franceschi, S. (2007) Worldwide variation in the relative importance of hepatitis B and hepatitis C viruses in hepato cellular carcinoma: A systematic review. British Journal of Cancer, 96, 11271134. doi:10.1038/sj.bjc. 6603649

[20] Khan, S., Rai, M.A., Khan, A., Farooq, A., Kazmi, S.U. and Ali, S.H. (2008) Prevalence of HCV and HIV infections in 2005-Earthquak areas of Pakistan. BMC Infectious Diseases, 8, 147. doi:10.1186/1471-2334-8-147

[21] Anonymous (1999) Global surveillance and control of hepatitis C. Journal of Viral Hepatitis, 6, 35-47. doi:10.1046/j.1365-2893.1999.6120139.x

[22] Waheed, Y., Shafi, T., Safi, S.Z. and Qadri, I. (2009) Hepatitis C virus in Pakistan: A systematic review of prevalence, genotypes and risk factors. World Journal of Gastroenterology, 15, 5647-5653. doi:10.3748/wjg. 15.5647

[23] Ali, S.A., Donahue, R.M.J., Qureshi, H. and Vermund, S.H. (2010) Hepatitis B and hepatitis C in Pakistan prevalence and risk factors. International Journal of Infectious Diseases, 13, 9-19. doi:10.1016/j.ijid.2008.06.019

[24] Umar, M., Bushra, H., Ahmad, M., Khurram, M., Usman, S., Arif, M., Adam, T., Minhas, Z., Arif, A., Naeem, A., Ejaz, K., Butt, Z. and Bilal, M. (2010) Hepatitis C in Pakistan: A review of available data. Hepatitis Monthly,
10, 205-214.

[25] Ali, A., Ahmad, H., Ali, I., Khan, S., Zaidi, G. and Idrees, M. (2010) Prevalence of active hepatitis c virus infection in district mansehra Pakistan. Virology Journal, 7, 334. doi:10.1186/1743-422X-7-334

[26] Zechini, B., Pasquazzi, C. and Aceti, A. (2004) Correlation of serum aminotransferase with HCV RNA levels and histological findings in patients with chronic hepatitis $\mathrm{C}$ : The role of serum aspartate transaminase in the evaluation of disease progression. European Journal of Gastroenterology \& Hepatology, 16, 891-896.

[27] Lee, Y.S., Yoon, S.K., Chung, E.S., et al. (2001) The Relationship of histologic activity to serum ALT, HCV genotype and HCV RNA titers in chronic hepatitis C. Journal of Korean Medical Science, 16, 585-591.

[28] Jensen, M.D., Morgan, T.R., Mercellin, P., Pockros, T.J., Reddy, K.R., Hadziyannis, S.J., Ferenci, P., et al. (2006) Early identification of $\mathrm{HCV}$ genotype 1 patients responding to 24 weeks peginterferon-2a (40 kd)/ribavirin therapy. Hepatology, 43, 954-960. doi:10.1002/hep.21159

[29] Bell, H., Hellum, K. and Harthug, S. (1997) Genotype, viral load and age as independent predictors of treatment outcome of interferon-a $2 \mathrm{a}$ treatment in patients with chronic hepatitis C. Scandinavian Journal of Infectious Diseases, 29, 17-22. doi:10.3109/00365549709008658

[30] Jimenez-Mendez, R., Uribe-Salas, F., López-Guillen, P., Cisneros-Garza, L. and Castañeda-Hernandez, G. (2010) Distribution of HCV genotypes and HCV RNA viral load in different geographical regions of Mexico. Annals of Hepatology, 9, 33-39.

IC: Internal control

ICT: Immunochromatographic test

M-MLV RT: Moloney murine leukemia virus reverse transcriptase

PEG-IFN: Pegelated interferon 